\title{
Impact of Maternal Employment on Adolescents Study Habits
}

\author{
Dr. Smritikana Mitra Ghosh ${ }^{1} *$
}

\section{ABSTRACT}

The purpose of the present study was to find out whether the study habits of school students of working differ significantly from those of non-working mothers. The sample of the study consisted of 200 school students (100 school students of working mothers \&100 school students of non- working mothers) studying in class Xth of Ranchi town. Study Habit Inventory constructed by Hassan (2003) of P.G. Department of Psychology, Ranchi University, Ranchi was administered to the selected sample to assess their study habits. The data so collected was analyzed statistically by employing mean, SD and t-test. The study revealed there were significant differences between the adolescent students of working and non- working mothers. Adolescents of working mothers had significantly better study habits than adolescents of non-working mothers. Further the study revealed that female students had significantly better study than male.

\section{Keywords: Study Habits, Adolescents, Working Mothers and Non-Working Mothers}

The first name which comes from baby's mouth is 'ma'. Mother is the first teacher of a child. Mother is the person who takes care of child's nutrition, hygiene, education than anyone else in the family. Working mother in the present study shall refer to educated women with educational qualification as graduation and above and is engaged in any government, semi-government or private salaried job. Non-working mother in the present study shall refer to educated women with educational qualification as graduation and above but not engaged in any government, semigovernment or private job. With the emergence of a new economic pattern, increasing opportunities for education, rising standard of living and increased modernization, women from the middle and upper class families have also started coming out of their traditional role of a home maker to join the work force. The number of working women has been increasing year by year. The education of women is not imperative for the benefit for the women only but uplift of the society also. Today women from all corners started working in government, semi government or private salaried jobs. The entry of women in the workforce brings changes in the structure and function of family. Every member of the family occupies a vital position in the

\footnotetext{
${ }^{1}$ Ph.D, Dept. of Psychology, Ranchi University, Jharknand, India

*Responding Author
}

Received: February 4, 2017; Revision Received: February 18, 2017; Accepted: February 24, 2017

(C) 2017 Ghosh S; licensee IJIP. This is an Open Access Research distributed under the terms of the Creative Commons Attribution License (www.creativecommons.org/licenses/by/2.0), which permits unrestricted use, distribution, and reproduction in any Medium, provided the original work is properly cited. 


\section{Impact of Maternal Employment on Adolescents Study Habits}

interaction map of the child but among them the role of mother is important and varied. Mother plays important role in the personality development of the children by shaping their intellectual and social behavour. The children of working and non working women differ in several areas.

\section{Concept of Study Habits}

Study habits are usually defined as student's ability to manage time and other resources to complete an academic task successfully. 'Study habit' is the amount and kind of studying routines which the student is used during a regular period of study occurred in a conducive environment. Study habits are the ways that we study, the habits that we have formed during our school years. Study habits can be good ones, or bad ones. Good study habits include being organized, keeping good notes, reading our textbook, listening in class, and working every day. Bad study habits include skipping class, not doing our work, watching TV or playing video games instead of studying, and losing our work. The definition of study habits are the behaviors used when preparing for tests or learning academic material. A person who waits until the very last night before an exam and then stays up all night trying to cram the information into his head is an example of someone with bad study habits. A habit is something that is done on a scheduled, regular and planned basis that is not relegated to a second place or optional place in one's life. It is simply done no reservations, no excuses, no exceptions. Crede and Kuneel (2008) defines study habit as study routines, including, but not restricted to, frequency of studying sessions, review of material, self testing, rehearsal of learned material and studying in a conducive environment. Study habits are commonly referred to as regular patterns in approaching study tasks. Study habits typically denotes degree to which students engages in regular acts of studying that are characterized by appropriate studying retains (review or material) occurring in an environment that is conducive to studying.

Study habits refer to the activities carried out by learners during the learning process of improving learning. Study habits are intended to elicit and guide one's cognitive processes during learning. Study habits are learning tendencies that enable students work privately. Study habits vary from student to student. Some habits are considered to be more desirable than others from the point of view of academic achievement. A good number of studies have been made in order to investigate the relationship between study habits and scholastic performance. Azikiwe (1998) describes study habits as "the adopted way and manner a student plans his private reading, after classroom learning so as to attain mastery of the subject". According to her, "good study habits are good asset to learners because habits helps students to attain mastery in areas of specialization and ensuing excellent performance, while the opposite becomes constraint to learning \& achievement leading to failure”. In recent years study skills and study habits or behaviors has been distinctly differentiated. Study habits of the children play very important role in reflecting the standards of education. Those Students who have good study habits are able to make effective study decisions, have the ability to differentiate the level of difficulty to learn the items, have high achievement motivation, socialized personality traits and problem solving 
appraisal. Without good study habits, a student cannot succeed. To succeed, students must be able to appropriately assimilate course content, digest it, reflect on it, and be able to articulate that information in written and/or oral form. Key is the ability to acquire effective study skills .Study skills: study skills are usually steps or procedures such as highlighting, outlining, notetaking, summarizing etc. that may be taught through explicit instruction (Gettinger \& Seibert, 2002). Study skills are the specific techniques that make up the study plan.

\section{REVIEW OF THE LITERATURE}

The research on the effects of maternal employment on the child indicates mixed results. In a review of research on maternal employment and children's achievement for the National Academy of Sciences, Heyns (1982) concluded that "the children of working mothers differ very little from the children of non-working mothers. Another review published 2 years before found that there were measurable differences in academic performance and other measures of children's well-being depending on maternal employment status (Hoffman, 1980). Scarr (1984) noticed that school achievement of children of employed mothers was good compared to children of nonemployed mothers but Gottfried and Bathurst (1988) in contrast, found that the number of hours the mothers work was negatively correlated with school achievement. Muni (1995) observed that adolescents of employed mothers had a positive physical, intellectual and educational selfconcept and were better adjusted than the children of housewives.

Blau (1999) determined that income was not as important a variable with respect to cognitive development in children as other familial aspects are. It was found that permanent income, that is income from a permanent career oriented position, is slightly significant. However, changing the families' income level has no significant effect. Children in different economic classes do seem to be on different cognitive levels. Maternal employment was found to be beneficial to children in low-income families. Perhaps these children receive more stimulation or education in their day care system than they would if they were at home. It can also be inferred that mothers of lowincome families are also less educated, thus having poorer parenting skills. The children of lowincome families with employed mothers scored higher on the cognitive tests and had less behavioural problems than children of low-income families where the mother was not employed.

Maternal employment may have more negative effects on child outcomes for children of twoparent families, high income or highly educated families (Gregg et al., 2005; Ruhm, 2004; \& Leigh \& Yamauchi, 2009). Research on maternal employment measured at the same time as the child outcome was reviewed recently in a meta-analysis by Goldberg et.al, (2008). They concluded from their analysis of 68 studies that the overall association between maternal employment and children's achievement, which was the sole child outcome in their analysis, was non significant. Children of non-working parent get higher grades in high schools, but at the same time feel less pressure about doing so (Essortment, 2002). Children of working mothers do not suffer any differently from anxiety, antisocial behavior or stress related problems than those 
of non-working mothers, had fever stereotyped gender-role attitudes and felt their mothers are more competent. Children of working mothers were also found to have a feeling of that they had control over their environment (Gershaw, 1988). Study conducted by Hoffman (1961) found that children of working mothers had lower intellectual performance than a matched group of children whose mother does not work. Some studies revealed that while the lack of mothers presence can impact a child negatively this impact is not as serve as what occurs if the mother does not work. Such factors include poverty, parental education and quality childcare (Booth, 2000). Abid (2006) revealed that guidance services have significant effect on the student's study attitudes, study habits and academic achievement. Significant differences were obtained in the academic achievement of students due to low and high level of goal orientation, study skills, scholarly study skills and over all study efficiency (Gakhar, 2005). Raiz et al. (2002) revealed that there existed a significant and positive relationship between achievement of the students and the said factors like schedule of study, habit of note taking and writing book. Franklin (2006) conducted a study to describe the study habits of undergraduate students who were enrolled in the initial phase of a teacher education programme at a large urban university.

The findings of the study indicate that a significant number of students study at home, cram the night before an examination, depends on other classmates to answer their questions, and feel that they spend an adequate amount of time preparing for academic classes. Lakshminarayanan et al. (2006) have made an attempt to compare achievers and non-achievers in study skills. Result in general indicates that achievers use higher level of study skills than non-achievers. Stella and Purushothaman (1993) examined the study habits of underachievers. The mean value showed that urban students had better study habits than rural students. Sud and Sujata (2006) who reported that girls have better study habits than boys. Suneetha and Mayuri (2001) also reported that boys and girls differ significantly in study habits. Harwod and Feruson (2000) and Akhani et al (1999) who reported that some areas of study habits are effected by maternal employment and some areas are not.

\section{Motivation of the research}

Researchers got interested in the field of education of children of working and non-working mothers, to find out the problems and benefits. Therefore, the importance of maternal employment inspired the researcher to conduct a study on study habits and maternal employment.

\section{Hypotheses}

1. There is no significant difference in study habits between adolescent students of working and non-working mothers.

2. There is no significant difference in study habits between male and female students. 


\section{Sample}

Sample of the present study consisted of male and female respondents of working and nonworking mothers, studying in class X of high schools of Ranchi city. The sample split of 100 students from adolescents of working mothers and (50 male and 50 female) and 100 students from adolescents of non-working mothers (50 male and 50 female).

\section{Research Variables}

1. Independent Variable -Maternal Employment

2. Dependent Variable - Study Habits

3. Intervening Variable - Male and Female Adolescents

\section{Tools used for Research}

Study Habit Test (SHT): Study habit test has been developed by Hassan (2003) of P. G. Department of Psychology, Ranchi University, Ranchi. The test covers 6 themes namely, revision, seriousness, systematic study habits, regularity, concentration and other than books. It is a four-point Likert type scale consisting of 24 items. Each item had four response alternatives: always, maximum times, sometimes and never. The responses alternatives to positive item are scored from 4 to 1 and to negative item are 1 to 4 . Thus, the total range of the score is from 24 to 96, the high scores indicating better study habits.

\section{Procedure}

The study habits test was administered to both groups with instructions to complete all questions honestly and not to discuss the questions with fellow students. Scoring was done according to the respective scoring keys. In order to fulfill the hypotheses of the study the score obtained were analysized with mean, SD’s and t value.

\section{Analysis of Data}

Data is by analyzed using statistical techniques like mean, SD and t-ratio. Bar diagrams graphs were drawn to make the results transparent.

\section{RESULT AND DISCUSSION}

Table -1: Means, SDs and t-ratios of adolescent students of working and non-working mothers on study habits

\begin{tabular}{|l|l|l|l|l|l|}
\hline $\begin{array}{l}\text { Study Habit } \\
\text { dimensions }\end{array}$ & Groups & N & Mean & SD & \multirow{2}{*}{ t } \\
\hline \multirow{2}{*}{ Revision } & Adolescents of working mothers & 100 & 12.87 & 3.06 & \multirow{2}{*}{$7.86^{* *}$} \\
\cline { 2 - 5 } & Adolescents of non working mothers & 100 & 9.96 & 2.08 & \\
\hline \multirow{2}{*}{ Seriousness } & Adolescents of working mothers & 100 & 11.59 & 3.44 & \multirow{2}{*}{$6.88^{* *}$} \\
\cline { 2 - 5 } & Adolescents of non working mothers & 100 & 8.92 & 1.79 & \multirow{2}{*}{$9.34^{* *}$} \\
\hline Systematic & Adolescents of working mothers & 100 & 12.46 & 2.71 & \\
\hline
\end{tabular}


Impact of Maternal Employment on Adolescents Study Habits

\begin{tabular}{|c|c|c|c|c|c|}
\hline $\begin{array}{l}\text { Study Habit } \\
\text { dimensions }\end{array}$ & Groups & $\mathbf{N}$ & Mean & SD & $\mathbf{t}$ \\
\hline Reading Habits & Adolescents of non working mothers & 100 & 9.39 & 1.86 & \\
\hline \multirow{2}{*}{ Regularity } & Adolescents of working mothers & 100 & 12.89 & 3.19 & \multirow{2}{*}{$7.82 * *$} \\
\hline & Adolescents of non working mothers & 100 & 9.87 & 2.17 & \\
\hline \multirow{2}{*}{ Concentration } & Adolescents of working mothers & 100 & 14.85 & 2.59 & \multirow{2}{*}{$11.18^{* *}$} \\
\hline & Adolescents of non working mothers & 100 & 11.07 & 2.17 & \\
\hline \multirow{2}{*}{$\begin{array}{l}\text { Other than } \\
\text { Books }\end{array}$} & Adolescents of working mothers & 100 & 10.86 & 2.22 & \multirow{2}{*}{$11.21^{* *}$} \\
\hline & Adolescents of non working mothers & 100 & 7.85 & 1.51 & \\
\hline \multirow{2}{*}{ Total } & Adolescents of working mothers & 100 & 69.08 & 8.91 & \multirow{2}{*}{$13.11^{* *}$} \\
\hline & Adolescents of non working mothers & 100 & 54.78 & 6.29 & \\
\hline
\end{tabular}

** Significant at 0.01 level

Figure -1: Showing mean scores of adolescent students of working and non-working mothers on study habits

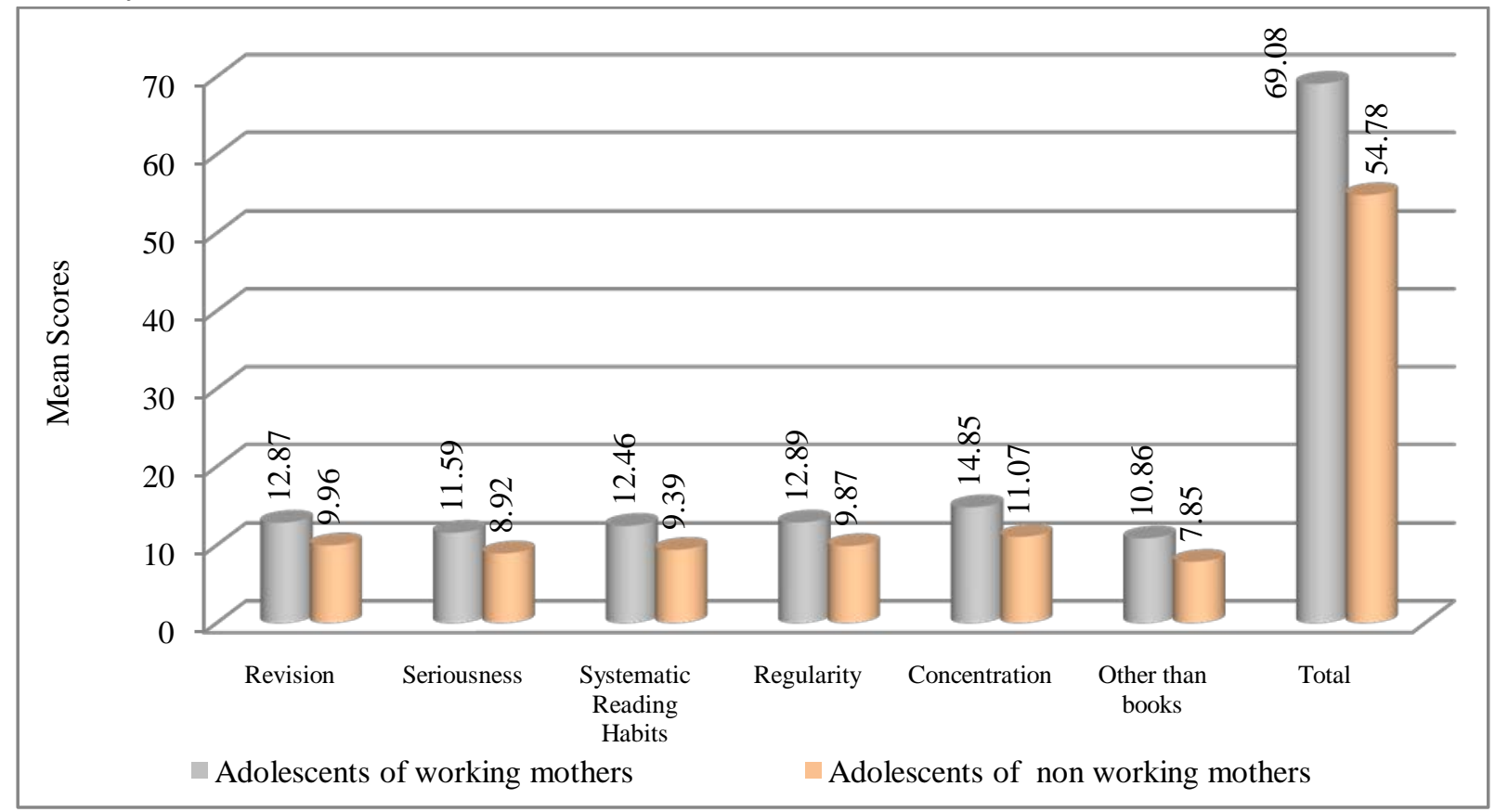

The above table- 1 depicts the mean scores of the student's adolescents of working mothers and non-working mothers on their study habits. The mean scores of working mothers group for revision, seriousness, systematic study habits, regularity, concentration, other than books and total study habits score is found to be 12.87, 11.59, 12.46, 12.89, 14.85, 11.07,10.86 and 69.08 and of non-working mothers group is found to be 9.96,8.92,9.39,9.87,11.07,7.85 and 54.78 respectively. All the t-values are statistically significant at 0.01 level of significance. It means adolescents of working mothers are better study habits than adolescents of non- working mothers.

(C) The International Journal of Indian Psychology, ISSN 2348-5396 (e)| ISSN: 2349-3429 (p) | 91 
Hence the hypothesis there is no significant difference in study habits between adolescent students of working and non-working mothers is rejected. The findings of the present study have support from the observation made by Harwod and Feruson (2000).

Table- 2 Means, SDs and t-ratios of male and female adolescents

\begin{tabular}{|c|c|c|c|c|c|}
\hline Study Habit dimensions & Groups & $\mathbf{N}$ & Mean & SD & $\mathbf{t}$ \\
\hline \multirow{2}{*}{ Revision } & Male & 100 & 9.87 & 2.51 & \multirow{2}{*}{$5.30^{* *}$} \\
\hline & Female & 100 & 11.96 & 3.04 & \\
\hline \multirow[b]{2}{*}{ Seriousness } & Male & 100 & 10.15 & 2.09 & \multirow{2}{*}{$6.69 * *$} \\
\hline & Female & 100 & 12.58 & 2.97 & \\
\hline \multirow{2}{*}{ Systematic Reading Habits } & Male & 100 & 9.12 & 2.42 & \multirow{2}{*}{$5.78^{* *}$} \\
\hline & Female & 100 & 11.79 & 3.93 & \\
\hline \multirow{2}{*}{ Regularity } & Male & 100 & 10.68 & 2.59 & \multirow{2}{*}{$7.11^{* *}$} \\
\hline & Female & 100 & 8.41 & 1.86 & \\
\hline \multirow{2}{*}{ Concentration } & Male & 100 & 9.15 & 2.68 & \multirow{2}{*}{$9.51^{* *}$} \\
\hline & Female & 100 & 12.85 & 2.82 & \\
\hline \multirow{2}{*}{ Other than Books } & Male & 100 & 13.15 & 2.47 & \multirow{2}{*}{$4.99 * *$} \\
\hline & Female & 100 & 11.56 & 2.01 & \\
\hline \multirow{2}{*}{ Total } & Male & 100 & 54.68 & 7.42 & \multirow{2}{*}{$5.59^{* *}$} \\
\hline & Female & 100 & 61.28 & 9.18 & \\
\hline
\end{tabular}

** Significant at 0.01 level

Figure -2: Showing mean scores of male and female adolescents

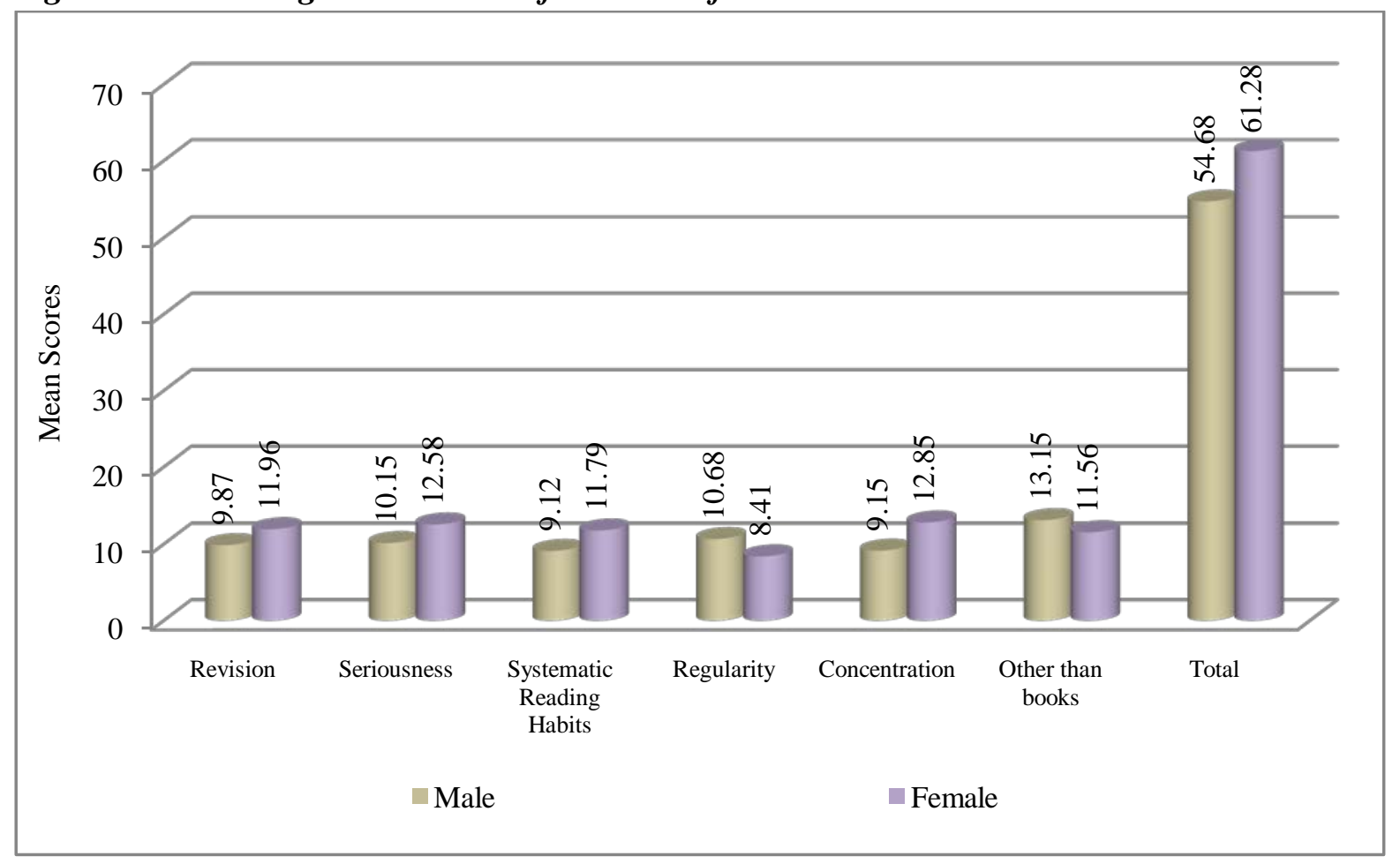


A glance of the table-2 depicts that there is a statistically significant difference found between male and female groups. It was seen that compared to the male group female group are having better studying skills. In all these comparisons between male and female adolescents, females have obtained significantly higher mean scores as compared to male adolescents. All the 't' ratios are significant at 0.01 level.

Hence the hypothesis "there is no significant difference in study habits between male and female students" is rejected. The findings about gender differences are in line with those of the studies by Suneetha and Mayuri (2001) and Sud and Sujata (2006).

\section{Findings of the study}

1. Adolescents of working mothers are better study habits than adolescents of non- working mothers.

2. Female adolescents are better study habits than male students.

\section{Limitations of the study}

1. The sample size for the present study was limited.

2. The present study included subjects from the urban localities of Ranchi only.

3. Variables like religion, area, age, types of family and socio-economic status etc. were not included in the study.

\section{Acknowledgments}

The author appreciates all those who participated in the study and helped to facilitate the research process.

Conflict of Interests: The author declared no conflict of interests.

\section{REFERENCES}

Akhani, P., Rathi, N., \& Jasore, M. (1999). Academic Achievement, Study Habits and Loneliness of Children of Employed and Unemployed Mothers. Journal of Psychometry and Education. 30(1), 65-57. Cited in Indian Educational Abstracts, 1(1), Jan. 2001, NCERT, New Delhi.

Blau, D. (1999). The Effect of Income on Child Development. Rev. Econ. Stat., 81: 261-277.

Ch. Abid, H. (2006). Effect of Guidance Services on Study Attitudes, Study Habits and Academic Achievement of Secondary School Students. Bulletin of Education \& Research, 28(1), 35-45.

Deka, N., \& Kakkar, A. (1998). The impact of maternal employment on perceived behavior and self-concept of Indian adolescents. Journal of Indian Academy of Applied Psychology, 24, 93-98.

Essortment. (2002). Children of Working Mothers. Essortment

Franklin, F.A. (2006). Study habits of Undergraduate Education Students. (Master's thesis). Retrieved from ProQuest Dissertations and Thesis. (UMI 1439951) 


\section{Impact of Maternal Employment on Adolescents Study Habits}

Gakhar, M. (2005). A Study of Academic Achievement of Bachelor of Psychotherapy Students Due to Different Study skills. Journal of Education \& psychology, 63(4), 31-37.

Goldberg, W. A., Prause, J. A., Lucas-Thompson, R., \& Himsel, A. (2008). Maternal employment and children's achievement in context: A Meta analysis of four decades of research. Psychological Bulletin, 134, 77-108. doi:10.1037/0033-2909.134.1.77.

Gregg, P., E. Washbrook, C. Propper \& S. Burges (2005), “The Effects of a Mother's Return to Work Decision on Child Development in the United Kingdom”, The Economic Journal, Vol. 115, pp. F48-F80.

Harwod, J.L. \& Ferguson, D.M. (2000). A longitudinal study of maternal labour force participation and child academic achievement. Retrieved from psychological Abstract, 2000, 84.

Heyns, B. (1982). The influence of parents' work on children's school achievement. In S. B. Kamerman \& C. D. Hayes (Eds.), Families that work: Children in a changing world (pp. 229-267). Washington, DC: National Academy Press.

Hoffman, L. W. (1980). The effects of maternal employment on the academic attitudes and performance of school-age children. School Psychology Review, 9, 319- 336.

Lakshminarayanan, T.R., Suresh, A., \& Kumari, K.A. (2006). Achievers and Non-Achievers Compared in Study Skills. Journal of Community Guidance \& Research, 23(3), 292-295.

Leigh, A. and C. Yamauchi (2009), “Which Children Benefit From Non-Parental Care?” (http://people.anu.edu.au/andrew.leigh/research.htm)

Mittal, S. (1997). Self-concept and scholastic achievement of children of working mothers and non-working mothers. Journal of Community Guidance and Research, 14, 47-52.

Muni, A.K. (1995). Effect of maternal employment on adolescents' self-concept and adjustment .International Journal of Behavioural Sciences, 13

Raiz, A., Kiran, A., \& Malik, N.H. (2002). Relationship of Study Habits with Educational Achievements. International Journal of Agriculture \& Biology. 4(3), 370-37.

Ruhm, C. (2004), "Parental employment and child cognitive development”, Journal of Human Resources, Vol. 39, No.1, pp. 155-92.

Scarr. (1984).Mother care-other care. New York: Basic Books.

Stella \& Purushothaman, S. (1993). Study habits of underachievers. Journal of Educational Research and Extension, 29(4), 206-214.

Sud, A., \& Sujata. (2006). Academic performance in relation to self-handicapping, test anxiety and study habits of high school children. Psychological Studies- University of Calicut, 51(4), 304-309.

Suneetha, B., \& Mayuri, K. (2001). A study on age and gender difference on the factors affecting high academic achievement. Journal of Community Guidence and Research, 18(2), 197208.

How to cite this article: Ghosh S (2017), Impact of Maternal Employment on Adolescents Study Habits, International Journal of Indian Psychology, Volume 4, Issue 2, No. 92, ISSN:2348-5396 (e), ISSN:2349-3429 (p), DIP:18.01.110/20170402, ISBN:978-1-365-78192-6 